\title{
Analysis of the Implementation of Distance Learning in the COVID-19 Pandemic New Normal Era
}

\author{
Muzanip Alperi ${ }^{*}$ - Thttps://orcid.org/0000-0002-9344-7519, Riyanto ${ }^{2}$, Johanes Sapri ${ }^{3}$, Alexon ${ }^{4}$, Dewi \\ Handayani ${ }^{*}$ ( \\ ${ }^{1}$ Education Quality Assurance Institutional of Bengkulu, Indonesia \\ 2,3,4,5Faculty of Teacher Training and Education, University of Bengkulu, Indonesia \\ *e-mail: 1*muzanip.alperi@kemdikbud.go.id, 5* ${ }^{*}$ d.handayani@unib.ac.id
}

\begin{tabular}{l}
\multicolumn{1}{c}{ Article Information } \\
\hline Received: March 11, 2021 \\
Accepted: March 29, 2021 \\
Online: May 11, 2021 \\
\hline \multicolumn{1}{c}{ Keywords } \\
\hline Distance Learning, COVID 19, New \\
Normal Era
\end{tabular}

\begin{abstract}
This research was conducted to see the implementation of distance learning during the New Habitual Adaptation (NHA) period of the COVID 19 pandemic. The indicators that will be seen are planning, implementation, problems, and solutions of distance learning. The method used in this research is a qualitative analysis method. The results of this study are(1) Learning planning for NHA mass education units in Kepahiang Regency has prepared related regulations, and an education unit ordinance has been issued related to its implementation. The infrastructure to prevent COVID 19 in the Kepahiang District education unit is also excellent. Therefore, the lesson plan that has been prepared has also been adjusted to the NHA period. (2) The implementation of AKB learning in Kepahiang Regency was actively followed by more than $80 \%$ of students, the most widely used learning method was offline distance, and the most widely used media was WhatsApp. (3) Obstacles faced in the learning process of the NHA period in the Kepahiang Regency are the facilities, networks, competencies, and complexity of the student's brain. (4) Solution options offered and carried out are offline distance learning. This research is essential because there are instruments whose indicators are determined according to the objectives achieved.
\end{abstract}

\section{INTRODUCTION}

The COVID 19 pandemic that has occurred in almost all countries requires a distance learning system. The goal of distance learning is to reduce its spread. In distance learning remains effective and maximizes children to continue learning. Online learning is an effective solution to activate classrooms even though schools are closed because time and place are at risk of this pandemic (Herliandry et al., 2020). According to Muhardi \& Ponidi (2020), online distance learning is effective because it involves students, parents and its implementation is directly monitored by the principal and by using signs.

Distance learning that was carried out during the COVID 19 pandemic in some places is considered surprising because so far, it has never implemented distance learning. Including Bengkulu, Indonesia. In rural schools in Kepahiang Bengkulu District, distance learning support facilities are still limited. Strategies and completeness are needed so that distance learning can be effective (Luh, N. et al., 2020)

Distance learning that is carried out still finds the best patterns to be effective and efficient. However, there are still many problems that arise at the implementation level of distance learning. The problems that arise in distance learning are teacher competence, facilities, internet networks, and 
student readiness (Sumarno, 2020). Parents must accompany children in online learning (Anugrahana, 2020). Student learning independence is also an obstacle, so that media that motivates independent learning is needed (Alperi M, 2019). Teacher and school factors still need more understand the essence of distance learning. Students have low learning independence, so they cannot regulate distance learning activities, teachers tend to stutter about technology, and parents do not understand the nature of teaching and learning activities (Churiyah, 2020).

Another obstacle. Students feel bored, so that it is less effective, facilities, busy parents ( $\underline{\text { Putria, } \mathrm{H}}$. et al., 2021). However, it has its advantages for schools that are ready for distance learning, including Listening at home, not limited by place, time, and learning with anyone ( Distance Learning will also improve IT skills and expand learning resources from various sources on the internet. In addition, the role of teachers is also needed in the planning process of mature learning activities, one of which is by selecting the suitable learning model (Handayani, D \& Alperi, M., 2021). According to Wati ER (2016), computer-based learning media always follows the times, including online learning. Online pursuit media, often referred to as e-learning, is a medium to support education and not as a substitute medium for education (Arsyad, 2011). Teachers cannot be replaced in teaching, but online learning based on computers and the internet needs to be mastered so as not left behind.

Distance learning has the same stages as face-to-face offline learning as usual. The difference is about the place, method, and learning media. If it is appropriate to apply it and minimize the obstacles faced, distance learning can be recommended. The important thing is to choose suitable media so that learning is effective and efficient (Utomo, MNY, et al., 2020). On the other hand, online distance learning is advantageous; it quickly learns and assesses suitable media, approaches, and strategies, including Blended Learning ( 2016). However, a mentor should be needed to stay focused.

To see the planning, implementation, constraints, and solutions of distance learning, it is necessary to conduct a survey of learning conducted by several schools that implement it. This survey was conducted by directly discussing the target schools and interviews regarding the required data. The Ministry of Education and Culture has made policies on learning during the COVID 19 pandemic, including Circular No. 4 of 2020. Continuous improvement of the quality of education is one of the learning objectives carried out. Therefore, the Ministry of Education and Culture needs to ensure that the quality of education continues to improve so that activities are carried out for guidance and monitoring of the implementation of distance learning.

This distance learning implementation analysis aims to describe the planning, implementation, constraints faced, and solutions to the problems. Achieving this goal will be measured by an instrument whose indicators are determined by the objectives. Some of the indicators measured in this analysis are planning, implementation, constraints, and solutions in distance learning.

\section{METHODS}

This research is a qualitative descriptive study using an online survey method. Sudjana (2001) defines descriptive research as "research that seeks to describe a symptom, event, occurrence that is happening at the moment." The characteristics of the descriptive method proposed by Nasution (2003) are focused on solving the latest problems. The data collected is compiled, described, and analyzed. Based on the above opinion, this study is intended to describe the conditions related to the implementation of the archival system and the effectiveness of decision making as they are or can describe the phenomenon as objectively as possible. As for the basis for researchers using descriptive methods, there are: (1). This research discusses actual, current, and present problems. (2). This method can provide an overview of the relationship between implementing archiving systems with the effectiveness of leadership decision-making. Make it easier for researchers to process data because the data collected is homogeneous or the same. (3). Besides being able to collect data, compile data, interpret data and conclude the data.

According to Winartha IM (2006), the qualitative descriptive analysis method analyzes, describes, and summarizes various conditions, situations from various data collected in interviews or observations regarding the problems under study that occur in the field. First, collecting data by making observations, interviews, and reviewing documentation. Data analysis through the stages of data reduction, data 
presentation, verification, and conclusions. The approach in research that will be carried out uses a qualitative approach or often referred to as a naturalistic approach (Suwardani, 2010). The qualitative approach is research to describe the object of research naturally (Sugiyono, 2018). This research is designed to obtain and describe data completely by taking essential steps related to implementing quality assurance of Islamic secondary schools. The research design to be carried out is multi-site research; multi-site research is a qualitative research design involving several sites (Suwardani, 2010). It is by design in the research conducted at the same place and has the same characteristics.

\section{Research procedure}

The research procedure that is used includes three processes. First, data collection and condensation data from interviews or documentation are analyzed, and important points are selected for their content. Second, the process of presenting data which the process of presenting data in a simple form arranged into sentences. Third, the leveraging process or concluding, namely the process of extracting the essence of data.

\section{Respondents}

The respondents in this study were 136 school principals, teachers, and education personnel in 30 schools in Kepahiang Regency. The details of the distribution of respondents are 20 school principals, 105 teachers, and 11 education personnel.

\section{Data collection}

Collecting data in this study using five data collection methods; 1 ) The instrument is in the form of a Google Form (the Bengkulu LPMP expert team has validated the instrument), 2) In-depth interviews, through zoom meetings 3) Participant observation, 4) Document study, 5) Coaching to each academic unit.

\section{Data and Analysis}

The data obtained were entered into the Microsoft Excel application, then a simple statistical analysis was made in the form of mean, mode, and recap of respondent's statements. Data is presented in graphs and tables. Data analysis describes Kepahiang District of the respondents who were targeted. The data analysis obtained is presented in detail based on facts and supported by previous relevant research data.

\section{RESULTS AND DISCUSSION Planning}

The instrument's distribution via google form and learning planning during the pandemic Corona Virus Disease (COVID-19) results can be displayed in the following explanation. Distance learning uses a variety of learning resources through a broader range of communication and information technologies. Distance learning that upholds the fulfillment of the right to education can be interpreted as education based on Pancasila and the 1945 Indonesian Constitution, where education must be implemented in a democratic, just, non-discriminatory manner and upholds human rights (Gunawan B, 2020). There are many regulations related to learning in the pandemic situation, including Minister of Education and Culture Circular Number 3 of 2020 Prevention of COVID-19 in the Education Unit, Circular of the Minister of Education, and Culture Number 4 of 2020 Implementation of Education Policies in an Emergency for the Spread of COVID-19, Kepmendikbud number 719/P/2020 Guidelines for implementing curriculum under special conditions, joint decisions of 4 ministers regarding learning during the COVID pandemic, and various other related regulations.

Schools in Kepahiang District already have learned related regulations and follow up through school regulations that were not contradicting the regulations above. Based on the data from interviews and document checking, all respondents (136) stated that the school had established regulations for implementing learning during the pandemic. It means that all schools in Kepahiang have made their most efforts to prevent the transmission of COVID 19, and learning continues. Furthermore, the learning plan for the pandemic period must also be prepared with supporting infrastructure for learning in the pandemic/new average period. In Kepahiang Regency, it was part of 
the green zone, so it was done face to face. Concerning face-to-face learning, infrastructure that supports learning during the COVID 19 pandemic is very much needed. After the interview, data is obtained as in Figure 1.

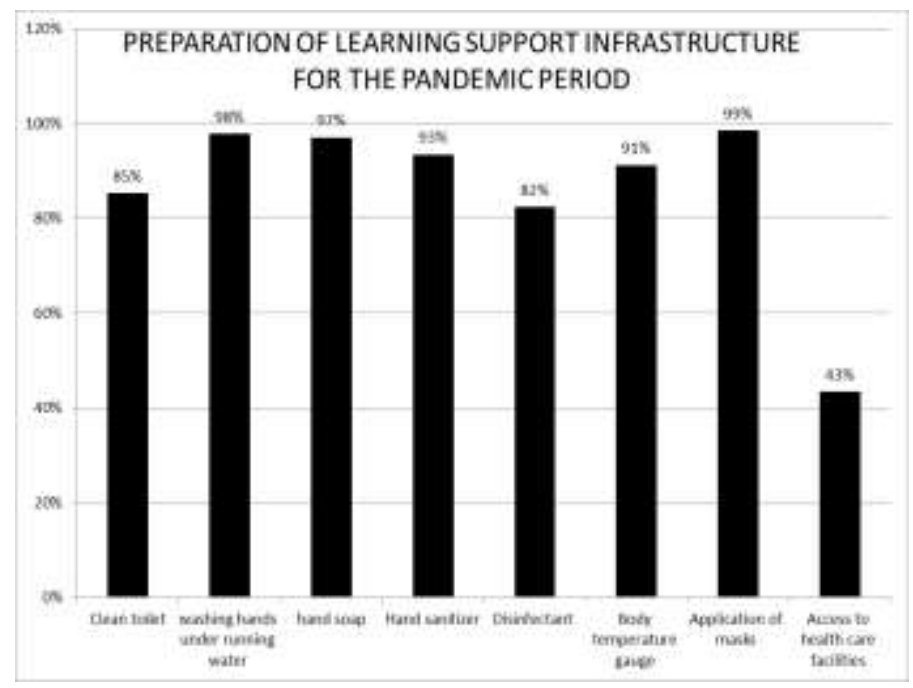

\section{Figure 1. Graphic Readiness of the New Habitual Adaptation (NHA) Period Infrastructure}

From Figure 1 above that more than $80 \%$ of respondents stated that they had prepared infrastructure in the form of mandatory wearing masks (99\%), temperature measurement (91\%), disinfectant (82\%), Hansanitizer (93\%), soap (97\%), Handwashing facilities (98\%), clean toilets (85\%). However, only $43 \%$ of respondents stated the availability of access to health service facilities.

According to the joint decree of 4 ministers and the learning guide, the New Habitual Adaptation (NHA) education units must provide access to health facilities. Access to the facilities in question is that if an illness occurs, especially if infected with COVID 19, students can immediately get standard health services such as UKS, Puskesmas, hospitals, or the health office. Respondents answered that they were not available because they understood that these facilities must be in the education unit, even though it was the provision of access to these facilities. Providing this access is, of course, the ease of transportation and communication to related parties. From further interviews, it was found that access to health facilities in Kepahiang was not difficult. The in-depth analysis results concluded that access to health facilities in target schools in Kepahiang District was easy. The thing that must be considered is the possibility of maintaining distance between students. It has been addressed by applying face-to-face no more than $50 \%$ of the class capacity. So that overall, the readiness of the education unit infrastructure in Kepahiang is seen as ready.

Online distance learning can be accepted as an educational solution in the face of the COVID-19 pandemic. However, it still requires improvements in terms of comfort, infrastructure, and knowledge absorption so that it does not just move classrooms into digital classrooms but also provides a holistic experience that makes it easier for students to study and gain knowledge (Daniel, 2021). The planning stage is also very important in preparing a Special Lesson Plan (SLP) during the pandemic/ new normal. Apart from being updated, the SLP also needs to pay attention to analyze their students' specific situations and circumstances. Each student and class group has different characters and abilities so that the same treatment of all students and class groups will result in a less than optimal learning process (Alfin, I., 2014). For teachers whose lesson plans have not been adjusted to the NHA period, a follow-up has been carried out by mentoring the preparation of the SLP for the NHA period. So that at the end of the activity, the teachers can make lesson plans by the NHA period. The lesson plan for the NHA period education unit in Kepahiang Regency has prepared related regulations, and an education unit regulation has been issued regarding its implementation. The infrastructure to prevent COVID 19 in the Kepahiang District education unit is also good. The lesson plan that has been prepared has also 
been adjusted to the NHA period. From the results of distributing questionnaires and interviews, data is obtained as shown in Figure 2.

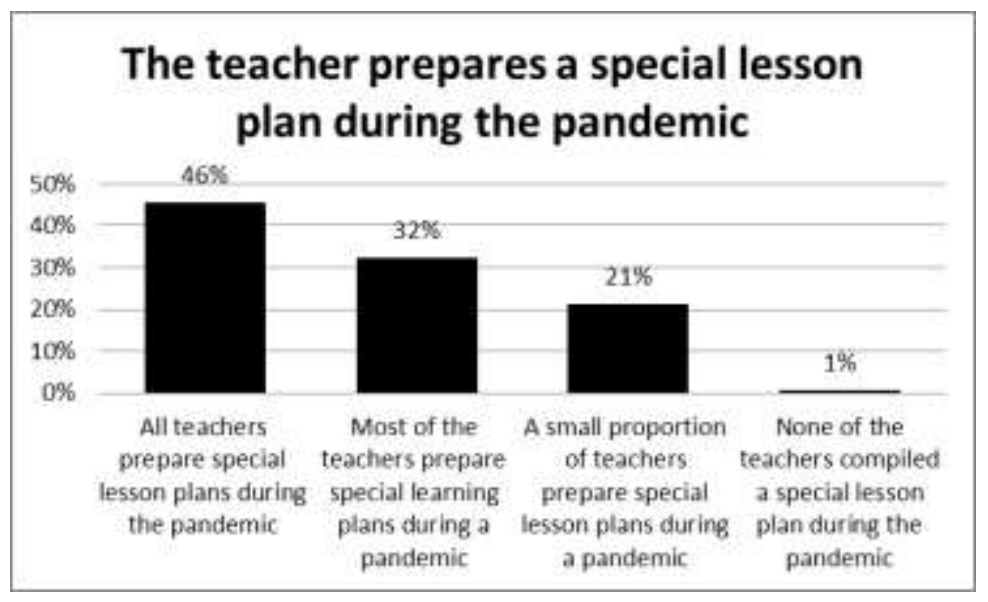

Figure 2. Graph of RPP Preparation for the New Habit Adaptation period

From Figure 2, the answers of respondents stating that all teachers prepare SLP NHA 46\% (62) of respondents, most of the teachers prepare SLP NHA 32\% (44) respondents, a small proportion of teachers prepare SLP NHA 21\% (29), none of the teachers make SLP NHA 1\% (1) of respondents. It shows that most teachers have made lesson plans for the New Habit Adaptation period. It means that most of the lesson plans made by the teacher updated according to the conditions of students.

\section{Implementation}

Percentage of students were able to take part in learning during the pandemic / new normal. The data obtained shows that more than $80 \%$ of students are taking lessons during a pandemic. The implementation of learning during the pandemic in Kepahiang Regency based on interviews with 136 respondents mentioned four main learning methods carried out during the IMR COVID 19 pandemic, namely online independent offline independent learning, face-to-face online learning, and face-to-face offline learning. The learning method used is based on interviews and questionnaires, as shown in Figure 3.

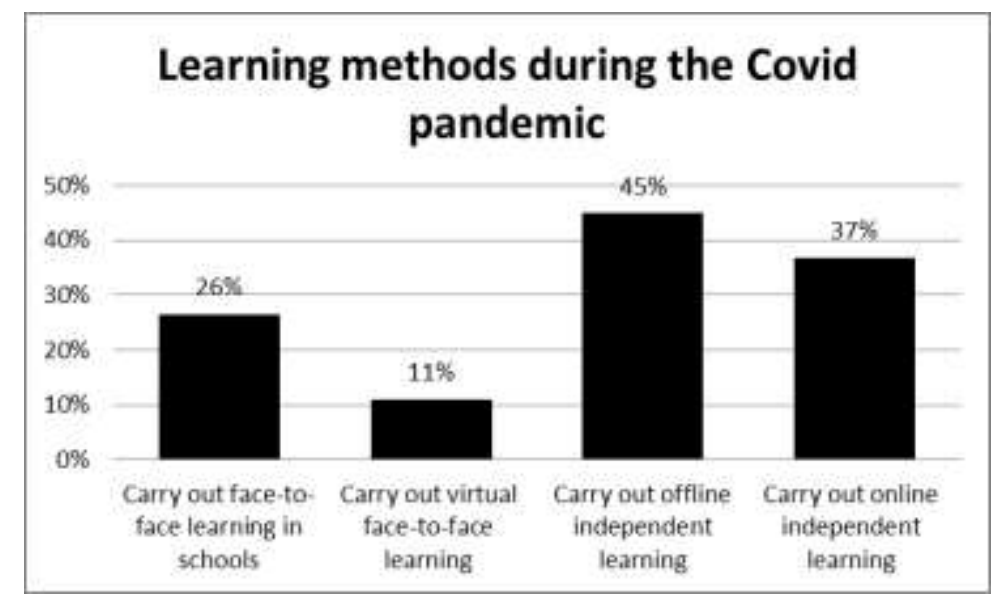

Figure 3. Graph of AKB Period Learning Implementation

Figure 3 shows that $45 \%$ (61) of respondents carry out offline independent learning. This learning form is a distance where students study the material and do assignments through modules/books given by the teacher. The assignment is delivered to the school, or the teacher picks up the student's home area. This online self-teaching is the method most widely used in Kepahiang 
Regency because this method can be overcome for students who do not have facilities. This learning can be used in all conditions, both in the city and in the village.

Furthermore, 37\% (50) of respondents stated that students study independently online. This online self-learning is in the form of distance learning which students use with the help of computers/cellphones and the internet. First, students are given an introduction by the teacher through virtual classes, including material and assignments in the virtual classroom. Then, students learn the material, do exercises, and find other source material independently.

Another learning method is face-to-face; face-to-face is divided into 2, namely online (virtual) and offline (at school). Face-to-face learning is considered adequate because students face the teacher directly; if there are direct questions, they can be answered. $26 \%$ (36) of the respondents said faceto-face learning at school from the questionnaires and interviews. However, face-to-face learning in schools still occurs in the green zone, and distance learning is impossible. Therefore, this learning is carried out as usual but still observes the health protocol with a class capacity of not more than $50 \%$.

Furthermore, from questionnaires and interviews, 11\% (15) of respondents stated face-to-face virtual learning. Although virtual face-to-face learning is through meeting rooms, this method is often referred to as synchronous. Media that can be used are zoom, Webex, google meet, Microsoft Teams, WhatsApp video call groups, and other suitable media. However, this media has weaknesses; it requires a computer/cellphone facility and an internet network and takes up quite a significant internet quota.

During the implementation of NHA learning, concern was the media/technology used during online distance learning. Several technologies are popularly used when online distance learning is as shown in Figure 4.

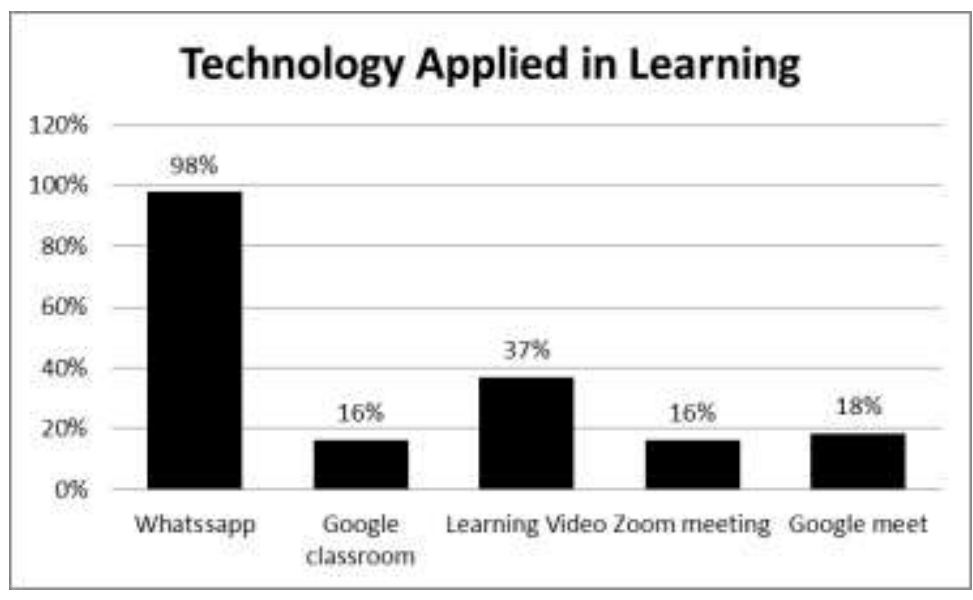

Figure 4. Technology Applied in Learning

Figure 4 shows that the technology used in distance learning with WhatsApp is $98 \%$ (133) of respondents. It means that $98 \%$ of respondents use WhatsApp as a learning medium. Whatsapp is the most widely used because WhatsApp is familiar to the community compared to other media. After all, almost all Android phones have this application. Learning videos came second with $37 \%$ (50) respondents, Google Meet 18\% (25) respondents, Zoom meeting and Google classroom 16\% (22) respondents respectively.

Using cellphones for children will positively impact Optimizing children's potential, and parental participation is the most crucial element in the formation and development of children's personalities (Pangestuti, R. 2017). Many research results show that WhatsApp is most popularly used as a learning medium during the COVID 19 pandemic. Learning using WhatsApp is effective in distance learning (Alubthane, SF \& ALYoussef, I. 2021). 100\% of teachers or as many as 64 teachers study with the WhatsApp application as the first choice. Furthermore, Google Classroom is the second option, Google form, YouTube, Zoom Cloud Meeting (Anugrahana, A., 2020). The majority of teachers use the WhatsApp group as a learning medium because of the wide range of uses and are very familiar to students and 
parents. In general, online distance learning is very good (Nugroho, YS, et al., 2021). The most important thing in online distance learning is the ease of accessing it. Online learning applications must be easy to access, use, attractive, and need to be combined with several applications to provide perfection in the delivery and acceptance of material in teaching and learning activities (Suryaman, Heri, et al., 2020)

More than $80 \%$ of students actively participated in the implementation of NHA learning in Kepahiang Regency, the most widely used learning method was offline distance, and the most used media was WhatsApp.

\section{Obstacles}

Of course, there are obstacles experienced by schools in implementing pandemic learning. From the results of questionnaires and interviews, whether there are obstacles faced in carrying out learning during the pandemic / new normal is shown in Figure 5.

\section{Obstacles}

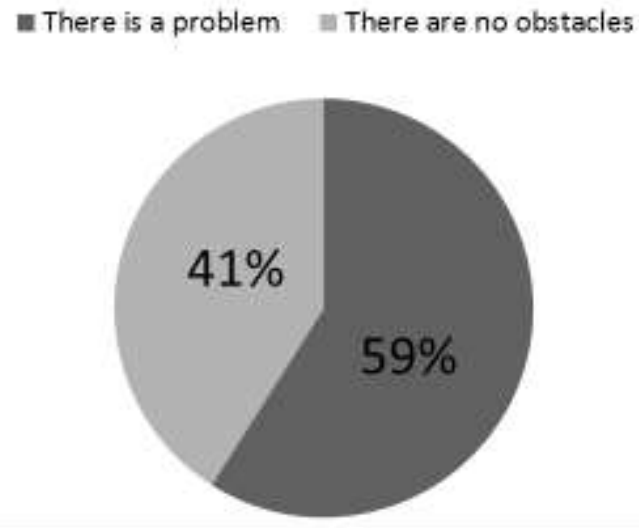

\section{Figure 5. Constraints faced during a pandemic}

More stated that there were obstacles than those who stated that there were no obstacles. Of the 136 respondents, 59\% (80 people) stated that there were obstacles in learning during the NHA period. We explore these constraints, and the details of the obstacles are Internet Network, Facilities (Laptop/Handphone), the ability of students to use distance learning facilities, competency of teachers, frequent power outages, Still awkward in undergoing distance learning. What is also an obstacle is the level of complexity of the student's different brains. A teacher must also pay attention to planning differences in the level of complexity of the student's brains. It is not enough for a teacher to only pay attention to essential competencies; the level of complexity of the student's brain must also be of concern to the teacher (Siregar, NS., 2018). The obstacles faced in the NHA learning process in Kepahiang Regency are the facilities, networks, competencies, and complexity of students' brains.

\section{CONCLUSION}

The conclusions of this study are: (1) The learning planning for the NHA mass education unit in Kepahiang Regency has prepared related regulations and the issuance of academic unit regulations related to its implementation. The infrastructure to prevent COVID 19 in the Kepahiang District education unit is also good. The lesson plan that has been prepared has also been adjusted to the NHA period. (2) More than $80 \%$ of students actively participated in implementing the NHA period learning in Kepahiang, the most widely used learning method was offline distance, and the most widely used media was WhatsApp. (3) The obstacles faced in the NHA learning process in Kepahiang Regency are the facilities, networks, competencies, and complexity of the students' brains. (4) Solution options offered and carried out are offline distance learning, student and teacher competency development, selecting appropriate media and learning methods, cooperation with parents, and careful and effective learning planning. 


\section{ACKNOWLEDGMENT}

Thank you to those who have helped in this research: (1) Head of the Bengkulu Province Quality Assurance Agency (LPMP), (2) Head of Kepahiang District Education Office, and (3) all parties involved in this study.

\section{Funding and Conflicts of Interest:}

The author's team declares that there is no funding and conflicts of interest for this research.

\section{REFERENCES}

Alfin, Jauharoti. (2014) Analisis karakteristik siswa pada tingkat Sekolah Dasar. In: Halaqoh Nasional dan Seminar Internasional Pendidikan Islam. http://digilib.uinsby.ac.id/id/eprint/30886.

Alperi M. (2019). Peran Bahan Ajar Digital Sigil dalam Mempersiapkan Kemandirian Belajar Peserta Didik. Jurnal Teknodik, 23( 2). 99-110. http://dx.doi.org/10.32550/teknodik.v0i1.479

Alubthanes, F \& Alyoussef, I. (2021). Pre-Service Teachers' Views about Effective Use of the Whatsapp Application in Online Classrooms: TOJET: The Turkish Online Journal of Educational Technology, 20(1). http://www.tojet.net/articles/v20i1/2016.pdf.

Anugrahana, A. (2020). Hambatan, Solusi dan Harapan: Pembelajaran Daring Selama Masa Pandemi Covid-19 oleh Guru Sekolah Dasar. Scholaria: Jurnal Pendidikan Dan Kebudayaan, 10(3), 282289. https://doi.org/https://doi.org/10.24246/i.js.2020.v10.i3.p282-289.

Arsyad, Azhar. (2011). Media Pembelajaran. Jakarta: PT. Raja Grafindo Persada.

Churiyah, M., Sholikhan, S., Filianti, F., \& Sakdiyyah, D. A. (2020). Indonesia Education Readiness Conducting Distance Learning in Covid-19 Pandemic Situation. International Journal of Multicultural and Multireligious Understanding, 7(6), 491. https://doi.org/10.18415/ijmmu.v7i6.1833.

Daniel Hermawan. (2021). The Rise of E-Learning in COVID-19 Pandemic in Private University: Challenges and Opportunities. IJORER: International Journal of Recent Educational Research, 2(1), 86-95. https://doi.org/10.46245/ijorer.v2i1.77.

Daryanto. (2016). Media Pembelajaran. Gaya Media: Yogyakarta.

Gunawan, B. (2020). Analisis Yuridis Pendidikan Jarak Jauh dalam Perspektif Hak Asasi Manusia dalam Undang-Undang Dasar NRI 1945 pada Masa Pandemi Covid-19 di Indonesia. Jurnal HAM, 11(3), 387. https://doi.org/10.30641/ham.2020.11.387-404.

Handayani, D., Alperi, M. (2021). Problem Solving Model Using Video Application. Journal of Physics: Conference Series, 1731. https://doi.org/10.1088/1742-6596/1731/1/012024.

Handayani, Lina. (2020). Keuntungan, Kendala dan Solusi Pembelajaran Online Selama Pandemi Covid-19 : Studi Ekploratif di SMPN 3 Bae Kudus. Journalindustrial Engineering\& Management Research(Jiemar),. 1(2). https://doi.org/10.7777/jiemar.v1i2.

Hergüner Gülten. (2021). The Effect of Online Learning Attitudes of Sports Sciences Students on their Learning Readiness to Learn Online in the Era of the New Coronavirus Pandemic (Covid-19). TOJET: The Turkish Online Journal of Educational Technology, 20(1), 68-77. http://www.tojet.net/articles/v20i1/2019.pdf.

Herliandry, L. D., Nurhasanah, N., Suban , M. E., \& Kuswanto, H. (2020). Pembelajaran Pada Masa Pandemi Covid-19.JTP - Jurnal Teknologi Pendidikan, 22(1), 65-70. https://doi.org/10.21009/jtp.v22i1.15286.

Kolak Ante dkk. (2021). When the Parent becomes the Teacher -Attitudes on Distance Learning in the Time of Corona-Teachingfrom Parents'Perspective. TOJET: The Turkish Online Journal of Educational Technology, 20(1). 85-94. http://www.tojet.net/articles/v20i1/20111.pdf. 
Luh, N., Nuraini, S., Qihua, S., Venatius, A. S., Slamet, T. I., \& Cholifah, P. S. (2020). Distance Learning Strategy in COVID-19. Proceeding International Webinar Series - Educational Revolution in Post Covid Era, 107-116. http://conference.um.ac.id/index.php/ksdp/article/download/110/112.

Muhardi, \& Ponidi. (2020). Pembelajaran Online yang Efektif di Masa Pandemi Covid-19 Studi Kasus di SMP Negeri 4 Pakem Sleman. Jurnal INTEK, 3, 11. https://doi.org/10.37729/intek.v3i1.568.

Nasution. (2003). Metode Penelitian Naturalistik Kualitatif. Bandung: Tarsito.

Nugroho, Y. S., Anifah, L., Sulistiyo, E., Cahyaningtias, S., \& Rifqi Firmansyah. (2021). Analysis of Learning Quality With Internet-Based Distance Learning During the COVID-19

Pandemic. IJORER: International Journal of Recent Educational Research, 2(1), 96-110. https://doi.org/10.46245/ijorer.v2i1.81.

Pangastuti, R. (2018). Fenomena Gadget dan Perkembangan Sosial bagi Anak Usia Dini. Indonesian Journal of Islamic Early Childhood Education, 2(2), 165-174. https://doi.org/10.51529/ijiece.v2i2.69.

Hilna, P., Luthfi, H. M., Din, A. U. (2021). Analisis Proses Pembelajaran dalam Jaringan (DARING) Masa Pandemi Covid- 19 Pada Guru Sekolah Dasar. Jurnal Basicedu, 4(4), 861-872. https://doi.org/10.31004/basicedu.v4i4.460.

Siregar, N. R., Mansyur, M., \& Muhammad, I. (2018). Teachers Need Neuro-Teaching Skills In The Classroom: A New Perspective For Better Future In Education. Social, Humanities, and Educational Studies (SHEs): Conference Series. https://doi.org/10.20961/shes.v1i1.23636.

Slamet, Slamet, and Amrullah, Abdul Malik Karim and Sutiah, Sutiah and Ridho, Ali (2021) Differences in the experience of lecturers and students on distance learning in higher education in Indonesia: A case study in the Pandemic of Covid-19. Systematic Reviews in Pharmacy, 12 (1). pp. 742-747. ISSN 0975-8453.

Sudjana. (2001). Metode \& Teknik Pembelajaran Partisipatif. Bandung : Falah Production.

Sugiyono. (2017). Metode Penelitian Kuantitatif, Kualitatif, R \& D.Bandung: CV Alfabeta

Sumarno (2020). Adaptasi Sekolah Dalam Mengimplementasikan Pembelajaran Jarak Jauh Pada Masa Pandemi Covid-19 (Studi Kasus SMP Muhammadiyah Karanggeneng Kabupaten Lamongan) . Jurnal Tarbiyah \& Ilmu Keguruan (JTIK) Borneo Institut Agama Islam Negeri Samarinda, 1(2). https://journal.iain-samarinda.ac.id/index.php/ITIKBorneo/article/view/2435.

Heri Suryaman, Kusnan, \& Husni Mubarok. (2020). Profile of Online Learning in Building Engineering Education Study Program During the COVID-19 Pandemic. IJORER: International Journal of Recent Educational Research, 1(2), 63-77. https://doi.org/10.46245/ijorer.v1i2.42.

Suwardani, E. (2010). Karateristik Anak Tuna Laras. Makalah pada PLB-FIP UNY, Yogyakarta.

Utomo, M. N. Y., Sudaryanto, M., \& Saddhono, K. (2020). Tools and Strategy for Distance Learning to Respond COVID-19 Pandemic in Indonesia. Ingenierie Des Systemes d'Information, 25(3), 383390. https://doi.org/10.18280/isi.250314.

Wati, E. R. (2016). Ragam Media Pembelajaran. Kata Pena : Yogyakarta.

Wirartha, I Made. (2006). Metode Penelitian Sosial Ekonomi. Yogyakarta: Andi Offset. 